\title{
Endocrine Pancreatic Control of the Release of Gastric Inhibitory Polypeptide
}

\section{A Possible Physiological Role for C-peptide}

\author{
Jill R. Dryburgh, S. M. Hampton, and V. Marks \\ Division of Clinical Biochemistry, Department of Biochemistry, University of Surrey, Guildford, Surrey, England
}

\begin{abstract}
Summary. Intravenous infusion in anaesthetized rats of rat II C-peptide at a dose which produced circulating levels of $22.8 \pm 1.8 \mathrm{nmol} / 1$ after $30 \mathrm{~min}$, resulted in a significant reduction $(141 \pm 7$ to $50 \pm 4 \mathrm{pmol} / \mathrm{l}$, $\mathrm{p}<0.001$, mean $\pm \mathrm{SEM})$ in the immunoreactive gastric inhibitory polypeptide response to an intestinal perfusion with a fat emulsion. Immunoreactive insulin levels were unchanged from basal in this study. It is suggested that C-peptide must be considered as a candidate for the endocrine pancreatic factor which exerts a negative feedback upon gastric inhibitory polypeptide release.
\end{abstract}

Key words: Gastric inhibitory polypeptide (GIP), control of GIP, intestinal perfusion with fat, rat GIP, rat $\mathrm{C}$-peptide, rat intestine.

It is strongly suspected that some factor of endocrine pancreatic origin is involved in negative feedback control of gastric inhibitory polypeptide (GIP) release $[1,2]$. GIP, released after ingestion of a mixed meal, is thought to play a major role in the intestinal regulation of insulin release in the presence of a degree of hyperglycaemia $[1,4,5]$. The most potent stimulus for GIP release is oral fat given to a normoglycaemic subject [6], the GIP response to an oral fat stimulus in the presence of hyperglycaemia being significantly less [7, 8]. Exogenous insulin [1], glucagon [9] and somatostatin [10] have all been shown to depress the GIP response to a stimulus, albeit at pharmacological levels. Recent studies in insulin-dependent juvenile-type diabetics suggest that insulin depresses fat- but not glucose-stimulated GIP release [2], although other workers have demon- strated insulin-induced attenuation of glucose-stimulated GIP release in dogs with Mann-Bollman fistulae [11]. The question of which pancreatic factor(s) exert control over GIP release under physiological conditions still remains to be answered.

$\mathrm{C}$-peptide is produced in the pancreatic B-cell when pro-insulin is converted to insulin, and is secreted in equimolar quantities with insulin $[12,13$, 14]. In 1968 Steiner et al. proposed that the function of C-peptide was to produce the folding of the proinsulin in such a way as to ensure that the disulphide bridges were correctly positioned [15]. However Wojcikowski and his co-workers have shown that in the isolated perfused rat pancreas exogenous administration of rat $\mathrm{C}$-peptide significantly depressed the release of arginine-stimulated insulin and glucagon [16], confirming and expanding the studies of Toyota et al. [17]. It still remains to be determined whether plasma C-peptide is merely a by-product of insulin synthesis, or whether it plays a biologically important role.

In this study the GIP response to fat, a situation where insulin levels remain unchanged, was monitored in the rat intestinal perfusion model of Watts et al. [18]. Using IV infusions we have tested whether C-peptide can influence the portal vein levels of GIP following gut perfusion with a soya bean emulsion.

\section{Materials and Methods}

\section{Animal Preparation}

Male rats of the Wistar strain (250-280 g body weight), fed on a normal laboratory diet, were used throughout. The animals were fasted for $24 \mathrm{~h}$ prior to each experiment, and were anaesthetized with IP pentobarbitone, $100 \mathrm{mg} / \mathrm{kg}$ body weight. The abdomen was opened along the midline and a catheter (Portex vinyl, $4 \mathrm{~mm}$ internal diameter) was inserted into the gut through a small inci- 


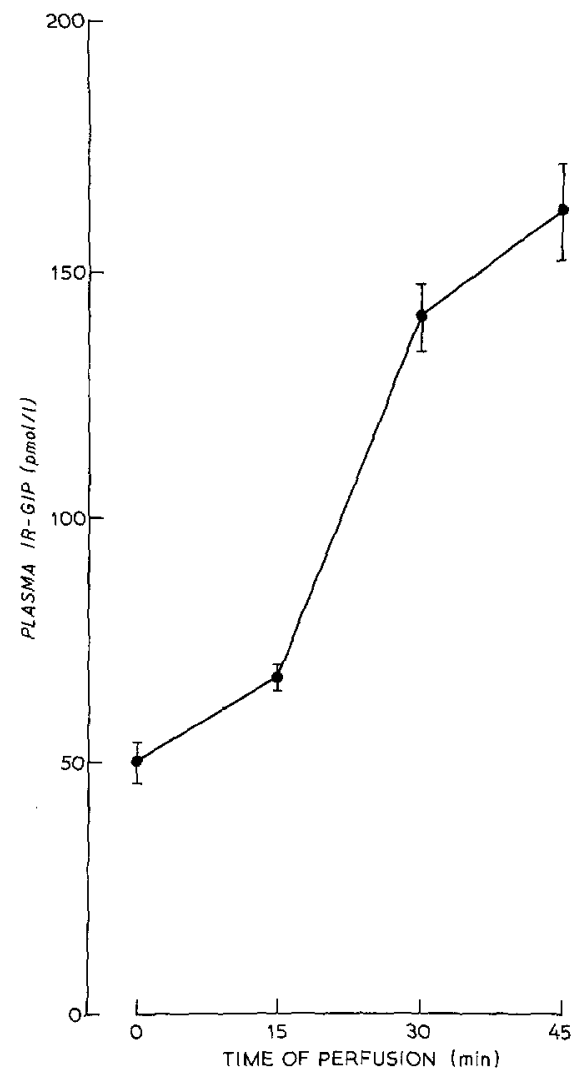

Fig. 1. The plasma GIP response to gut perfusion with Intralipid $10 \%$ for $0,15,30$ and $45 \mathrm{~min}$, in anaesthetized rats. Mean \pm SEM $(\mathrm{n}=6)$

Table 1. Effect of varying Intralipid $10 \%$ gut perfusion times on immunoreactive GIP and insulin, and blood glucose, in anaesthetized rats. Results are given as mean \pm SEM

\begin{tabular}{rlll}
\hline $\begin{array}{l}\text { Time of } \\
\text { perfusion }\end{array}$ & $\begin{array}{l}\text { Plasma } \\
\text { GIP } \\
\text { pmol/1 }\end{array}$ & $\begin{array}{l}\text { Plasma } \\
\text { insulin } \\
\mathrm{mU} / 1\end{array}$ & $\begin{array}{l}\text { Blood } \\
\text { glucose } \\
\text { mmol/1 }\end{array}$ \\
\hline $0 \mathrm{~min}$ & $50 \pm 3$ & $20.5 \pm 3.7$ & $3.9 \pm 0.25$ \\
$15 \mathrm{~min}$ & $67^{\mathrm{a} \pm 2}$ & $21.6 \pm 3.2$ & $5.1 \pm 0.60$ \\
$30 \mathrm{~min}$ & $141^{\mathrm{a}} \pm 7$ & $23.6 \pm 5.3$ & $3.0 \pm 0.13$ \\
$45 \mathrm{~min}$ & $163^{\mathrm{a}} \pm 9$ & $18.0 \pm 3.5$ & $5.3 \pm 0.50$ \\
\hline
\end{tabular}

a $p<0.001$ compared with the control at $0 \mathrm{~min}$

sion in the region of the duodenal bulb. A second small incision was made in the terminal ileum and the intestinal contents were flushed out with Krebs-Ringer phosphate buffer, pH 7.4, at $37^{\circ} \mathrm{C}$. A vinyl catheter was then placed in this lower incision to allow free drainage of gut perfusates. A small polyethylene cannula (Intramedic PE 20), attached to a 26 gauge needle, was placed in the external jugular vein and kept patent with $0.154 \mathrm{~mol} / 1$ saline. The upper catheter was attached to a peristaltic pump, allowing perfusion of the gut with either Krebs-Ringer phosphate buffer, pH 7.4 , or Intralipid $10 \%$, a commercial preparation containing fractionated soya bean, egg lecithen and glycerol at neutral $\mathrm{pH}$ (Vitrum, Stockholm, Sweden). The IV cannula was connected to a syringe pump for the infusion of either saline or C-peptide.
Initially the gut was perfused with Intralipid $10 \%$ for 15,30 or $45 \mathrm{~min}, 0.154 \mathrm{~mol} / \mathrm{l}$ saline being given IV, and portal blood samples were taken by venipuncture at the appropriate time. After measuring the GIP content of the samples the $30 \mathrm{~min}$ period was chosen for all subsequent perfusions.

\section{Experimental Protocol}

A. Gut perfusion with Krebs-Ringer phosphate buffer ( $\mathrm{pH} 7.4$, $37^{\circ} \mathrm{C}$ ) at $2 \mathrm{ml} / \mathrm{min}$ for $30 \mathrm{~min}$ : IV saline $(0.154 \mathrm{~mol} / \mathrm{l}) 0.12 \mathrm{ml} / \mathrm{min}$ for $30 \mathrm{~min}$, starting simultaneously $(\mathrm{n}=6)$.

$B$. Gut perfusion with Intralipid $10 \%, 2 \mathrm{ml} / \mathrm{min}$ for $30 \mathrm{~min}$ : IV saline as in $(A)(n=6)$.

C. Gut perfusion with Intralipid $10 \%$ as in (B): IV infusion with rat II C-peptide, $0.12 \mathrm{ml} / \mathrm{min}$ for $30 \mathrm{~min}$. The final concentration of C-peptide in $0.154 \mathrm{~mol} / 1$ saline received by the rat was $250 \mathrm{ng} /$ $\min / \mathrm{kg}$ body weight $(\mathrm{n}=6)$.

$D$. IV infusion of C-peptide alone, as in (C). $(n=6)$. (Purified synthetic rat II C-peptide, lot No.NY-YI-4-48, was kindly donated by Professor N. Yanaihara, Shizuoka, Japan).

At the end of $30 \mathrm{~min}$ the IV infusion and gut perfusion were discontinued. The portal vein was exposed and 2-3 ml blood were taken by syringe and placed in a heparinised tube. A $100 \mu 1$ aliquot of whole blood was deproteinised with tungstate and stored at $-20^{\circ} \mathrm{C}$ for the determination of blood glucose by the method of Trinder [19]. Plasma for the hormone assays was stored at $-20^{\circ} \mathrm{C}$.

\section{Analytical Methods}

Plasma insulin was measured by radioimmunoassay, using antiinsulin serum (Wellcome guineapig RD10, K4671) and iodinated insulin (Radiochemical Centre, Amersham, IM 38, specific activity $11 \mathrm{kBq} / \mathrm{pmol}$ ). The standard was human insulin (Wellcome RD13, $\mathrm{K} 4005$ ), which was incubated in hormone-free rat plasma. Parallelism of the rat insulin with the human insulin standards was verified. The antibody-bound antigen was precipitated with donkey anti-guineapig serum (Guildhay Antisera, HP/D/231C). The sensitivity of the assay was $4 \mathrm{mU} / 1$ (defined as $2 \mathrm{SD}$ from zero), and the interassay coefficient of variation $<6.2 \%$.

Immunoreactive GIP was measured by the method of Morgan et al. [20]. The porcine standards were incubated in hormone-free plasma and the crossreactivity of the antiserum with porcine and rat GIP correlated well. The assay sensitivity was $21.5 \mathrm{pmol} / \mathrm{l}$ and the inter- and intra-assay coefficients of variation were $18.6 \%$ at $100 \mathrm{pmol} / \mathrm{l}$ and $8.2 \%$ respectively.

Immunoreactive $\mathrm{C}$-peptide determinations were performed by a modification of the method of Yanaihara et al. [21]. The antiserum (R-901) was raised in a rabbit against rat II C-peptide but is known to recognize both forms of rat $\mathrm{C}$-peptide. The standards were rat II C-peptide, over the range $0-10 \mathrm{ng} / \mathrm{ml}$. The label was prepared by incorporation of ${ }^{125} \mathrm{I}$-sodium into $\mathrm{N}$-terminallytyrosylated synthetic rat $1 \mathrm{C}$-peptide by means of the chloramine- $\mathrm{T}$ oxidation technique, with subsequent purification of the iodinated peptide by elution from Sephadex G-10 in $40 \mathrm{mmol} / \mathrm{I}$ phosphate buffer, pH 7.4, containing $0.5 \mathrm{~g} / 100 \mathrm{ml}$ bovine serum albumin (BSA). The standards (in hormone-free rat plasma) and unknowns were incubated with the antiserum for $24 \mathrm{~h}$ before the addition of ${ }^{125}$ I-C-peptide in $40 \mathrm{mmol} / 1$ phosphate buffer containing $1 \mathrm{~g} /$ $100 \mathrm{ml}$ BSA. Twenty hours after the addition of the label, separation of the antibody-bound antigen was effected by a second antibody, donkey anti-rabbit serum (Guildhay Antisera HP/D12/ VIA). The sensitivity of the assay was $46 \mathrm{pmol} / 1$ and the coefficient of variations were $11.5 \%$ at $4.9 \mathrm{nmol} / 1$ (inter-assay) and $<7 \%$ (intraassay). 


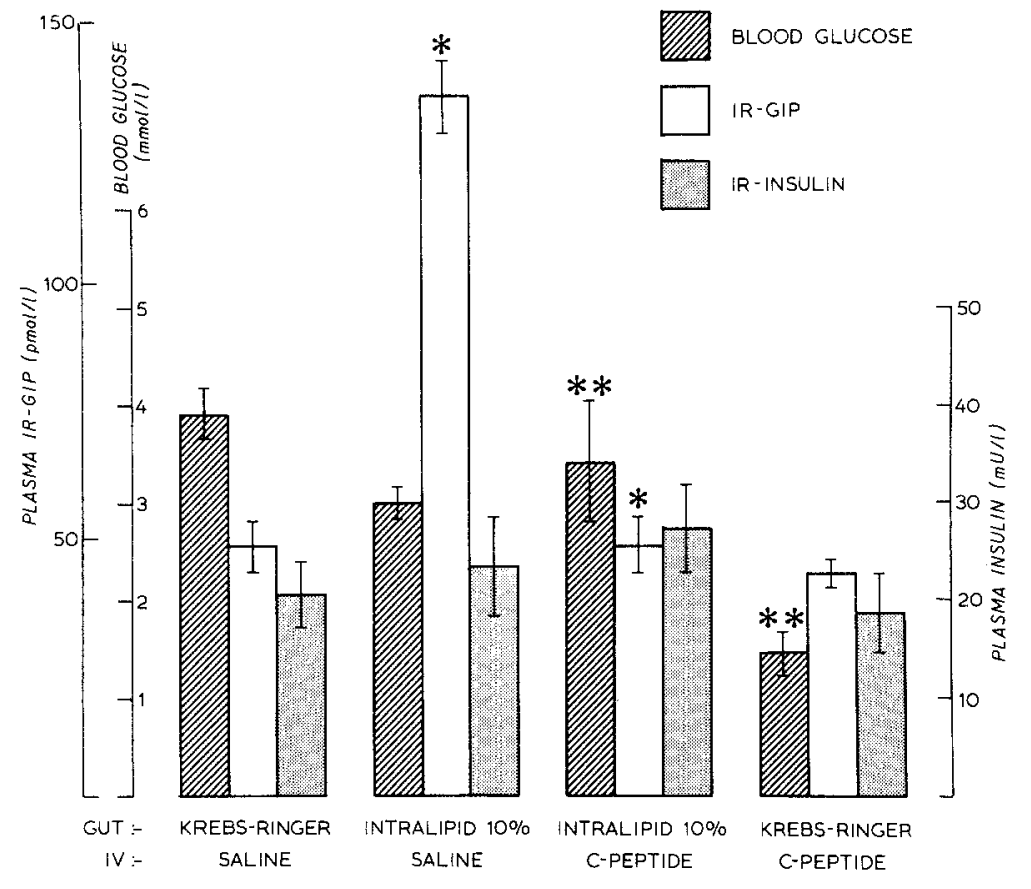

Fig. 2. The plasma GIP, plasma insulin and blood glucose response to IV infusion with saline ( $0.154 \mathrm{~mol} / \mathrm{l})$ or rat II C-peptide, during gut perfusion with Intralipid $10 \%$ or Krebs-Ringer phosphate buffer, $\mathrm{pH} 7.4$, in anaesthetized rats Mean \pm $\operatorname{SEM}(n=6)(*=p<0.001, * *=p<0.01)$

\section{Expression of Results}

Results are expressed as mean \pm SEM. Significance was assessed using Student's t-test.

\section{Results}

The GIP response to gut perfusion with a fat emulsion is shown in Figure 1. The $\mathbf{3 0}$ min perfusion was adopted for all subsequent experiments. The GIP response was significantly increased $(p<0.001)$ in comparison with the control (Krebs-Ringer phosphate buffer, $\mathrm{pH} 7.4$ perfusion) but was less than that measured after $45 \mathrm{~min}$ perfusion, suggesting that the GIP cells were not secreting maximally. There was no significant change in plasma insulin or blood glucose levels (Table 1).

Intravenous infusion with synthetic rat II C-peptide during gut perfusion with Intralipid 10\% produced a total inhibition of the GIP response to the fat $(50 \pm 4 \mathrm{pmol} / \mathrm{l}$ compared to $141 \pm 7 \mathrm{pmol} / \mathrm{l}, \mathrm{p}<$ 0.001 ), although the plasma insulin and blood glucose were not affected (Fig. 2 and Table 2). Intravenous infusion of rat II C-peptide alone did, however, depress the blood glucose $(\mathrm{p}<0.01)$. The $\mathrm{C}$-peptide levels achieved during exogenous administration of the peptide were $22.8 \pm 1.8 \mathrm{nmol} / \mathrm{l}$.

C-peptide was also measured in portal blood samples taken from rats with had been starved for $24 \mathrm{~h}$, half of which were then allowed free access to standard rat laboratory food and had been observed to have eaten voraciously for $1 \mathrm{~h}$ before the sample was taken. The fasting and fed values of $\mathrm{C}$-peptide in these rats were $1.7 \pm 0.2 \mathrm{nmol} / 1$ and $7.8 \pm 0.7 \mathrm{nmol} / 1$ respectively ( $\mathrm{n}=12$ for each group).

\section{Discussion}

Watts et al. [18] perfused the intestine of anaesthetized rats with glucose and demonstrated a highly significant GIP response in portal blood by $15 \mathrm{~min}$, which had plateaued by $30-45 \mathrm{~min}$. In the current study intestinal perfusion with a fat emulsion produced a slower rise in portal GIP levels which were significant by $30 \mathrm{~min}$ but had increased further at $45 \mathrm{~min}$. This confirms the finding in dogs [1] and man [6] that the GIP response following oral fat differs from that observed after oral glucose in timing. This may be explained by the differing rates of absorption of these nutrients. Creutzfeldt et al. showed that glucose had to be absorbed to effect the release of GIP [22] and it would appear that only actively transported sugars are capable of stimulating GIP secretion [23]. The time course of GIP release after fat stimulation indicates that absorption is also essential for fat-stimulated GIP secretion. Poor absorption of the fat content of a mixed stimulus has been postulated as being responsible for some of the abnormalities of GIP release observed in certain disease states, characterized by malabsorption $[24,25,26]$. 
Table 2. Effect of intravenous saline $(0.154 \mathrm{~mol} / 1)$ or rat C-peptide on immunoreactive GIP and insulin, and blood glucose during gut perfusion with Intralipid $10 \%$ or Krebs-Ringer phosphate buffer $\left(\mathrm{pH} 7.4,37^{\circ} \mathrm{C}\right)$ in anaesthetized rats

\begin{tabular}{|c|c|c|c|c|}
\hline Protocol & Plasma GIP, pmol/1 & Plasma insulin, $\mathrm{mU} / 1$ & Plasma C-peptide, $\mathrm{nmol} / 1$ & Blood glucose, $\mathrm{mmol} / \mathrm{l}$ \\
\hline $\begin{array}{l}\text { Gut: Krebs-Ringer } \\
\text { IV: Saline }\end{array}$ & $50 \pm 3$ & $20.5 \pm 3.7$ & \multirow[t]{2}{*}{$2.6 \pm 0.3$} & $3.9 \pm 0.3$ \\
\hline $\begin{array}{l}\text { Gut: Intralipid } \\
\text { IV: Saline }\end{array}$ & $141^{a} \pm 7$ & $23.6 \pm 5.3$ & & $3.0 \pm 0.1$ \\
\hline $\begin{array}{l}\text { Gut: Intralipid } \\
\text { IV: C-peptide }\end{array}$ & $50^{\mathrm{a}} \pm 4$ & $27.1 \pm 3.9$ & \multirow[t]{2}{*}{$22.8 \pm 1.8$} & $3.4^{b} \pm 0.4$ \\
\hline $\begin{array}{l}\text { Gut: Krebs-Ringer } \\
\text { IV: C-peptide }\end{array}$ & $45 \pm 2$ & $18.5 \pm 3.7$ & & $1.4^{b} \pm 0.2$ \\
\hline
\end{tabular}

${ }^{\mathrm{a}} \mathrm{p}<0.001,{ }^{\mathrm{b}} \mathrm{p}<0.01$

The GIP response to a meal appears to be determined by the balance between absorption of nutrients and a negative feedback of endocrine pancreatic origin. The present study suggests that $\mathrm{C}$-peptide must be added to the list of possible candidates for the role of pancreatic mediator since at concentrations only three times those encountered in the normal fed rat it completely abolished the GIP response to intrajejunal fat.

An interesting finding was the depression of the blood glucose values in the group of animals which received $\mathrm{C}$-peptide alone. This could be due to $\mathrm{C}$ peptide-induced inhibition of glucagon release, described by Wojcikowski et al. [16], or possibly by stimulation of somatostatin release, which would contribute to the depression of the GIP response [10]. This aspect of the response to C-peptide infusion requires further investigation.

Pathological conditions characterized by an exaggerated GIP response to stimulation include several in which insulin (and therefore C-peptide) secretion is deficient, such as untreated juvenile-onset diabetes [27], mild chronic pancreatitis $[24,25]$ and after duodenopancreatectomy [28]. In other disease states such as untreated maturity-onset diabetes [1] and obesity associated with abnormal glucose tolerance [29] the elevated GIP response in the presence of hyperinsulinaemia and raised C-peptide levels has been explained in terms of a reduction in the numbers of insulin receptors on the GIP cell, a functional deficit in the controlling factor [29]. This same postulate could be applied to C-peptide, in place of insulin.

Confirmation that C-peptide is a metabolically active peptide must await studies investigating the GIP response to a more physiological stimulus, when the C-peptide levels are in the normal postprandial range. Nevertheless these results suggest that C-peptide is not the biologically inert substance it was once believed to be.
Acknowledgements. We should like to thank Professor N. Yanaihara for his kindness in donating the C-peptide antiserum and the purified synthetic C-peptide used for the standards and label preparation. We are also grateful to Guildhay Antisera for financial support. Jill R. Dryburgh is in receipt of a Post-doctoral Fellowship from the MRC (Canada).

\section{References}

1. Brown JC, Dryburgh JR, Ross SA, Dupre J (1975) Identification and actions of gastric inhibitory polypeptide. Recent Prog Horm Res 31: 487-532

2. Creutzfeldt W, Talaulicar M, Ebert R, Willms B (1980) Inhibition of gastric inhibitory polypeptide release by insulin and glucose in juvenile diabetics. Diabetes 29: 140-145

3. Kuzio M, Dryburgh JR, Malloy KM, Brown JC (1970) Radioimmunoassay for gastric inhibitory polypeptide. Gastroenterology 66: 357-364

4. Marks V, Turner DS (1977) The gastrointestinal hormones with particular reference to their role in the regulation of insulin secretion. Essays Biochem 3: 109-152

5. Creutzfeldt W (1979) The incretin concept today. Diabetologia $16: 75-85$

6. Falko JM, Crockett SE, Cataland S (1975) Gastric inhibitory polypeptide (GIP) stimulated by fat ingestion in man. Endocrinol Metab 41: 260-265

7. Cleator IGM, Gourlay RH (1975) Release of immunoreactive gastric inhibitory polypeptide (IR-GIP) by oral ingestion of food substances. Am J Surg 130: 128-135

8. Ross SA, Dupre J (1978) Effects of ingestion of triglyceride or galactose on secretion of gastric inhibitory polypeptide and on response to intravenous glucose in normal and diabetic subjects. Diabetes 27: 327-333

9. Ebert R, Arnold R, Creutzfeldt W (1977) Lowering of fasting and food stimulated serum immunoreactive gastric inhibitory polypeptide (GIP) by glucagon. Gut 18: 121-127

10. Pederson RA, Dryburgh JR, Brown JC (1975) The effect of somatostatin on release and insulinotropic action of gastric inhibitory polypeptide. Can J Physiol Pharmacol 53: $1200-1205$

11. Sirinek KR, Pace WG, Crockett SE, O'Dorisio TM, Mazzaferri EL, Cataland S (1978) Insulin-induced attenuation of glucose-stimulated gastric inhibitory polypeptide. Am J Surg 135: $151-155$

12. Clark JL, Cho S, Rubenstein AH, Steiner DF (1969) Isolation of a pro-insulin fragment from bovine and human pancreas. Biochem Biophys Res Commun 35: 456-461 
13. Kemmler W, Peterson JD, Steiner DF (1971) Studies on the conversion of pro-insulin to insulin. I. Conversion in vitro with trypsin and carboxypeptidase. J Biol Chem 246: 6786-6791

14. Kemmler W, Peterson JD, Rubenstein AH, Steiner DF (1972) On the biosynthesis, intracellular transport and mechanics of conversion of pro-insulin to insulin and C-peptide. Diabetes 21 [Suppl 2]: 572-581

15. Steiner DF, Hallund O, Rubenstein AH, Cho S, Bayliss G (1968) Isolation and properties of pro-insulin, intermediate forms and other components from crystalline bovine insulin. Diabetes 17: 725-736

16. Wojcikowski C, Fussganger RD, Pfeiffer EF (1977) Inhibition of insulin and glucagon secretion of the isolated rat pancreas by synthetic human and rat C-peptide. In: Beyer J, Krause U, Naegele W (eds) Proc 1st Int Symp on C-peptide, Mainz. Schnetztor-Verlag, Konstanz, p 75-94

17. Toyota T, Abe K, Kudo M, Kimura K, Goto Y (1975) Inhibitory effects of synthetic rat C-peptide I on insulin secretion in isolated perfused rat pancreas. Tohuku J Exp Med 117: 79-83

18. Watts C, Morgan L, Marks V (1978) Liver glycogen metabolism during intestinal perfusion in the rat. Life Sci 23: 2429-2436

19. Trinder $P$ (1969) Determination of blood glucose using 4amino phenzone as an oxygen acceptor. J Clin Pathol 22: 246

20. Morgan LM, Morris BA, Marks V (1978) Radioimmunoassay of gastric inhibitory polypeptide. Ann Clin Chem 15: 172-177

21. Yanaihara C, Ozaki J, Nishida T, Iizuka Y, Sato H, Yanaihara N, Kanako T (1979) Immunological studies on synthetic rat and guinea pig C-peptides. In: Baba S, Kaneko T, Yanaihara N (eds) Proinsulin, insulin and C-peptide. Excerpta Medica, Amsterdam, p 87-93

22. Creutzfeldt W, Ebert R (1977) Release of gastric inhibitory polypeptide (GIP) to a test meal under normal and pathological conditions in man. In: Bajaj JS (ed) Diabetes. Proc. IDF, New Delhi. Excerpta Medica, Amsterdam, p 63-75

23. Sykes S, Morgan LM, English J, Marks V (1980) Evidence for preferential stimulation of gastric inhibitory polypeptide secretion in the rat by actively transported carbohydrates and their analogues. J Endocrinol 85: 189-192

24. Ebert R, Creutzfeldt W, Brown JC, Frerichs H, Arnold R (1976) Response of gastric inhibitory polypeptide (GIP) to a test meal in chronic pancreatitics, relationship to endocrine and exocrine insufficiency. Diabetologia 12: 609-612

25. Botha JL, Vinik AI, Child PT (1978) Gastric inhibitory polypeptide in acquired pancreatic diabetes: effects of insulin treatment. J Clin Endocrinol Metab 47: 543-549

26. Besterman HS, Cook GS, Sarson DL, Christofides N, Bryant MG, Gregor M, Bloom SR (1979) Gut hormones in tropical malabsorption. Br Med J II: 1252-1255

27. Ebert R, Creutzfeldt W (1978) Aspect of GIP pathology. In: Bloom SR (ed) Gut hormones. Churchill Livingstone, Edinburgh, p 294-300

28. Creutzfeldt W, Ebert R, Arnold R, Frerichs H, Brown JC (1976) Gastric inhibitory polypeptide (GIP), gastrin and insulin: response to test meal in coeliac disease and after duodenopancreatectomy. Diabetologia 12: 279-286

29. Creutzfeldt W, Ebert R, Willms B, Frerichs H, Brown JC (1978) Gastric inhibitory polypeptide (GIP) and insulin in obesity: increased response to stimulation and defective feedback control of serum levels. Diabetologia 14: 15-24

Received: May 30, 1980,

and in revised form: July 10,1980

Dr. J. R. Dryburgh

Laboratory for Endocrine Physiology and Pharmacology

National Institute for Medical Research

The Ridgeway

Mill Hill

London NW7 1AA

England 